\title{
Pronouns in Ode Dialect: A Grammatical Analysis
}

\author{
Oluwole Samuel Akintoye \\ Department of Linguistics and Nigerian Languages, Ekiti State University of Ado Ekiti, Ado Ekiti, Nigeria \\ Email: akinwolesam1@gmail.com
}

Received 24 October 2014; revised 7 December 2014; accepted 21 December 2014

Copyright (C) 2014 by author and Scientific Research Publishing Inc.

This work is licensed under the Creative Commons Attribution International License (CC BY). http://creativecommons.org/licenses/by/4.0/

c) (i) Open Access

\begin{abstract}
Much attention has been paid on the pronouns in the Yoruba language by the Yoruba scholars compared to the few works on the pronouns in the dialects of Yoruba. This paper contributes to the few works on the pronouns in the dialects of Yoruba. The paper considers the pronouns in Ode, a sub-dialect of Èkìtì, and discusses the similarities and differences observed between the pronouns in Yoruba language and Ode dialect. The paper applies a descriptive approach in its analysis.
\end{abstract}

\section{Keywords}

Dialect, Sub-Dialects, Pronouns, Subject, Object, Singular, Plural, Mutual Intelligibility

\section{Introduction}

Ode dialect, a sub-dialect of Ekiti, is located in the South east of Ekiti-State and it is the headquarters of Gbonyin Local Government Area. Ode dialect speech form resembles Ìrùn, Ògbàgì and Àfìn dialects of Àkókó (Olumuyiwa, 2009). This might be due to the closeness to the aforementioned dialects and this also might be the reason that its speech form differs from the speech forms of other sub-dialects of Ekiti in spite of the mutual intelligibility. In addition, the difference noticed may also be as a result of distance (Trudgill \& Chamber, 1980; Edward, 2011: pp. 1-5). If that is the case, our point will be in consonance with Trudgill and Chamber (ibid.) who are of the opinion that the more two or more dialect communities are far from one another the more their speech forms differ.

The data for the research work were collected from the community where the dialect is being spoken. Because the author is a native speaker of the dialect and he speaks it fluently, this made it possible for him to interact with the language consultants who are also the native speakers of the dialect and they have spent most of their life times in the community. The paper is purely analytical. Our major business is to present the data and analyze 
how they are used in the dialect, hence, the research work shall be based on descriptive approach.

This paper investigates the pronouns of Ode dialect, a sub-Ekiti dialect of Yoruba, and points out the areas in which it differs from other sub-dialects of Ekiti and Yoruba language. The paper is divided into three sections. Section one is the introduction of this paper. Section two examines the various aspects of pronouns in Òdè dialect. Section three focuses on the interaction between pronouns and negation.

\section{Pronouns in Òdè Dialect}

Many Yoruba scholars such as Bamgbose (1967: pp. 22-24; 1990: pp. 157-160), Awobuluyi (1978: pp. 76-80), Yusuf (1995) and Adewole (1996: pp. 56-61) who have worked on the pronouns in Yoruba language define a pronoun as the word used instead of a noun. Bamgbose (1967: pp. 22-24) views a pronoun as a word that cannot have a qualifier in the nominal group. He says further that pronouns have a system of number (singular and plural) and of person $\left(1^{\text {st }}, 2^{\text {nd }}\right.$ and $3^{\text {rd }}$ person $)$. They also have different forms for the different syntactic positions. Awobuluyi (1978: p. 78) refers to pronouns as polymorphic nouns which take three forms when they function as subject, object and qualifiers. Adewole (1996: p. 57) supplies us more information about pronouns by explaining the differences between the pronouns in Yoruba language and the dialects of Yoruba. For instance, Adewole (ibid.) is of the opinion that singular subject pronouns have two forms which obey vowel harmony principle in Ifè dialect as shown below.

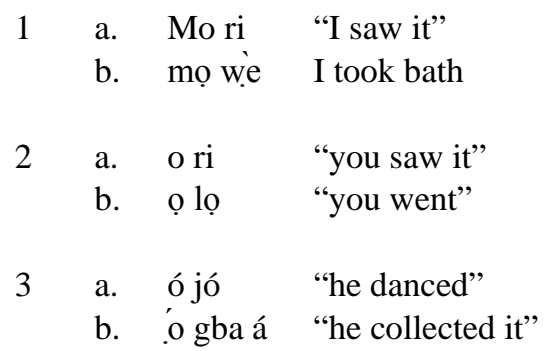

In the examples above, mo, o and ó in examples 1(a), 2(a) and 3(a), co-occur with the vowel sounds /i// and /o/ which are [+ ATR] while mọ, $\mathbf{0}$ and $\mathbf{0}$ in examples1(b), 2(b) and 3(b) co-occur with the vowels /ẹ/, /ọ/ and /a/ which are [+ATR]. It is obligatory to lengthen the final syllable of qualifier pronoun in If̣e dialect as reflected in ọmọ rin-ín "your child”. Though such deletion is noticed in Yoruba language, this is possible when the possessive marker ti is deleted as demonstrated below.
4 a.
i.
ii
Ilé ti wa $\rightarrow \quad$ ilé $\varnothing$ wa $\rightarrow$
ii
ilé e wa
"our house”
b. àga ti Șadé $\rightarrow$ àga ø Șadé $\rightarrow$
àga a Șadé
"Sade’s chair"

In examples $4 \mathrm{a}$ (ii) and b(ii) above, the possessive marker ti is deleted. This gives rise to the vowel lengthening as shown in $4 \mathrm{a}$ (iii) and b (iii). The type of vowel lengthening discussed here is not attested in If̣e dialect because there is no trace of deletion between the qualifier rin and ín. A critical look at our discussion reveals that majority of the Yoruba scholars who have worked on pronouns concentrate on Yoruba language. The research work will be a contribution to the clarion call of Awobuluyi (1998: p. 10) that attention should be given to carrying out research on the dialects of Yoruba so as to increase our knowledge on the sounds and the terminology of the dialects.

Pronoun in Òdè dialect can be grouped according to their functions in construction and they have a system of numbers and of persons just as what operates in Yoruba language (Bamgbose, 1990: pp. 157-160).

\subsection{Subject}

$\begin{array}{lll} & \text { Singular } & \text { Plural } \\ \text { First person } & \text { mi } & \text { a } \\ \text { Second person } & \text { wo/ wọ } & \text { in } \\ \text { Third person } & \text { o/ọ/e/ẹ } & \text { ọn }\end{array}$

The first person singular pronoun takes mi-form both in simple sentences and when it collocates with a progressive marker í and it does not obey vowel harmony principle. 


$\begin{array}{lll}5 & \text { a. } & \text { mí lọ } \\ & & \text { 1sg go } \\ & \text { I went } \\ & & \text { mí ri } \\ \text { b. } & \text { 1sg see } \\ & \text { I saw him } \\ & \text { mì í lọ } \\ \text { c. } & \text { 1sg PROG go } \\ & \text { I am going } \\ & \text { mì í jẹun } \\ \text { d. } & \text { 1sg PROG eat } \\ & \text { I am eating. }\end{array}$

The above examples are contrary to some other sub -dialects of Èkìtì where first person singular pronouns are in variants mo, mọ, me and mẹ and they all obey vowel harmony principle (Adewole, 1996). Mo and me collocate with /i//, /o/, /e/ and /u/ while mọ and mẹ co-occur with /ẹ/, /ọ/ and /a/. The only difference between these variants is that $\mathbf{m o}$ and $\mathbf{m o}$ occur in simple sentences while me and mẹ collocate with progressive marker.

\section{Adó dialect}

6 a. $\quad$ mo r

1 sg see

I saw it

b. mo gbe

1 sg carry

I carried it

c. mọ lọ

1sg go

I went

d. mọ jẹun

1 sg eat

I ate

7 a. mè i sùn

1sg PROG sleep

I am sleeping

b. mè i gbe

1sg PROG carry

I am carrying it

c. mịe i lọ

1sg PROG go

I am going

d. mịe i jẹun

1sg PROG eat

I am eating

Apart from that, the second person wo and wo also obey vowel harmony principle in that wo co-occurs with $\mathbf{i}$, $\mathbf{e}, \mathbf{o}, \mathbf{u}$ and wọ occurs with a, ẹ, ọ. 
8
a. wọ lo
2sg go
You went
b. wọ á
2sg come
You come
c. wọo jẹ
2sg eat
You ate
d. wó ri
2sg see
You saw it
e. wo gbe
2sg carry
You carried it

The third person pronoun has four forms in this dialect. $\mathbf{O}$ and $\mathbf{0}$ are employed in a simple construction, while e and ẹ are also employed in a progressive, and they all obey vowel harmony.

9 a.

o ri

3sg see

He saw him

b. ó gbe

3sg carry

He carried it

c. $\quad$ o kà

3sg confess

He confessed

d.

o gbe

3sg dry

It dried

e. 'o gbó

3sg hear

He heard

10 a. e í bì

3sg PROG vomit

He is vomiting

b. e í gbe

3sg PROG carry

He is carring it

c. ẹ í kà

3sg PROG confess

$\mathrm{He}$ is confessing

d. ẹi gbẹ 
3sg PROG dry

It is drying

Another thing to consider is that when first and second person singular pronouns co-occur with the future marker á, they lose their features and assimilate the feature of the future marker á as illustrated below.

11 a

mì á á $\rightarrow$ mà á á

1sg FUT come

I will come

b. $\quad$ mì á ri $\rightarrow$ mà á ri

1sg FUT see

I will see it

c. wio á á $\rightarrow$ wà á á

2sg FUT come

You will come

d. wò á ri $\rightarrow$ wà á ri

2sg FUT see

You will see it

When the second and third person plural pronouns on and ín collocate with the progressive marker í and future marker á, the markers í and á assimilate the pronouns feature.

12 a.

ìn í bò $\rightarrow$ ìn ín bọo

2pl PROG come

You are coming

b. ìn í jẹun $\rightarrow$ ìn ín jẹun

2pl PROG eat

You are eating

c. òn í bòo $\rightarrow$ on ín bọo

3pl PROG come

They are coming

d. on í jẹun $\rightarrow$ on ín jẹun

3pl PROG eat

They are eating

9 a. ìn á lọ $\rightarrow$ ìn án lọ

2pl FUT go

You will go

b. $\quad$ ìn á jẹun $\rightarrow$ ìn án jẹun

2pl FUT eat

You will eat

c. .on á lọ $\rightarrow$ òn án lọ

3pl FUT go

They will go

d. $\quad$ ọn á jẹun $\rightarrow$.on án jẹun

3pl FUT eat

They will eat 


\subsection{Objects}

$\begin{array}{lll} & \text { Singular } & \text { plural } \\ \text { First person } & \text { mi } & \text { a } \\ \text { Second person } & \text { o } & \text { in } \\ \text { Third person } & \text { un } & \text { ọn }\end{array}$

The difference between the first person singular subject pronoun mí and the object pronoun mi is tone. For instance, $\mathbf{m i}$ in the subject position takes a high tone, while it takes a mid tone in the object position. Apart from that, the third person singular object takes un form.

13 a. í é rí un

Say NEG see 3sg

He said that he did not see him

b. $\quad$ íe gbọo un

say NEG hear 3sg

he said that he did not hear him

The reason why we can accept that the third person singular object takes un form is that it is sub-categorized by the verbs like other object pronouns as illustrated below:

14 a. í é rí o

Say NEG see 2sg

He said that she did not see you

b. $\quad$ í é rí mi

say NEG see 1sg

he said that she did not see me

However, un only operates in a negative construction.

Apart from this, the second and third person object pronouns take in and on forms respectively, and they are different from their subject counterparts by tone. For instance, subject second and third person pronouns take a high tone while they take a mid tone in the object position. There is also the likelihood for the second person subject pronoun to change tone, especially when it occurs in an imperative construction

15 a. ìn á!

2pl come

You come!

b. ìn sùn!

2pl sleep

You sleep!

The tonal change in the above examples is determined by the verbs that sub-categorize them. For instance, if the verbs take a low tone, the tone of the pronouns will change to a high one.

16 a. á gbà ín

1 pl take $2 \mathrm{pl}$

We accepted you

b. mi gbà on

1 sg take 3pl

I accepted them

\subsection{Genitive Pronouns}

Genitive pronouns are used to qualify a noun in a noun phrase. They are employed to indicate ownership. Genitive plural pronouns take consonant initial in Ode dialect so as to differentiate it from the object pronouns. More so, their tone does not change if they collocate with another noun in an NP structure:

17 a. ulé ra

House $1 \mathrm{pl}$ 
Our house

b. $\quad$ ulé rin

house $2 \mathrm{pl}$

your house

c. ulé ron

house 3pl

their house

\section{The Interaction between Pronouns and Negation in Òdè Dialect}

Negation is a conversion of affirmative or positive statements to negative statements. It can also be used to deny an earlier statement or assumption made by someone (Osten, 1979: p. 79). Negative marker takes è and éi forms in Òdè dialect. The difference between them is that éi is deployed to negate focused and relativized NPs, and it occurs in the initial position of the constructions and always collocates with the verb-șe:

18 a.

éi șe Olú kì mí í wí

NEG do Olú REL 1sg PROG say

It is not Olú who I am talking about

b. $\quad$ éi șe Olú li.on rí

NEG do Olú FOC 3pl see

It was not Olú that they saw.

The negative marker-è is used to negate a complete sentence and it occurs in a median posi tion. Assimilation occurs between the negative marker and pronouns, such that the negative marker assimilates the feature of the vowels of the pronouns:

19 a.

mí è lọ $\rightarrow$ mí ì lọ/mí lọ

1sg NEG go

I did not go

b. $\quad$ mí è ri $\rightarrow$ mí ì ri/mí ri

1 sg NEG see

I did not see it

c. ín è lọin $\rightarrow$ ín ìn lọ

2pl NEG go

You did not go

d. .on è á $\rightarrow$ on on á

3pl NEG come

They did not come

e. wó è ri $\rightarrow$ wó ò ri/wó ri

2sg NEG see

You did not see it

f. wó̀ jẹ $\rightarrow$ wóo o jẹ/ẉo jẹ

2sg NEG eat

You did not eat

g. é è ri $\rightarrow$ é è ri/é ri

3sg NEG see

He did not see it 


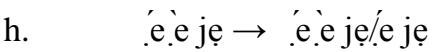

3sg NEG eat

He did not eat

It is important to note that the structures without assimilation occur in a fast speech, whereas, the assimilated ones are used in a slow speech. As already stated in Section 1.1, the third person singular pronoun has four forms; e and e forms are selected to collocate with a negative marker and these two variants obey vowel harmony principle as illustrated above. In addition, the difference between examples 1(c) and (d) and 16(a) and (b) is tone. For instance, examples 1(c) and (d) take low tone, while examples 16(a) and (b) take high tone.

Some differences are observed between the pronouns in Òdè dialect and the other sub-dialects of Ekiti and the standard Yoruba. For instance, the first person singular subject pronoun has only one form mi and this form does not obey vowel harmony principle while this pronoun has four forms $\mathbf{m o} / \mathbf{m o}$ and me/me in some other sub-dialects of Ekiti as illustrated in examples 2 and 3 above. However, the first person singular pronoun has one variant mo in the standard Yoruba. Following Awobuluyi's (1992: pp. 12-38) and Adewole's (ibid.) claims, it is evident that the first person pronoun $\mathbf{m i}$ is the underlying structure for $\mathbf{m o}$ and $\mathbf{m o}$.

Finally, genitive pronouns are derived by vowel lengthening, especially in sub-dialects like İjerò, Tèmídire, Kóró Ayégún!̣e to mention a few.

17
a.
a. ulé ria
house our
our house
b. $\quad$ ulé rin-ín
house your
your house
c. ulé ri-ọn
house their
their house

İjerò dialect

\section{Conclusion}

This paper has examined the pronouns in Òdè, a sub-dialect of Ekiti and it has pointed out the areas in which the pronouns in Ode dialect are different from what we have in Yoruba language. For instance, the first person subject and object pronouns have the same form mi. The difference between them is marked by tone. The first person singular subject pronoun takes high tone, whereas, the first person singular object takes mid tone. The negative marker $\mathbf{e}$ assimilates the feature of the second syllable of the subject NP adjacent to it. This paper will serve as a contribution to the existing works on the pronouns in the dialects of Yoruba.

\section{References}

Adewole, L. O. (1996). If̣e Pronouns in Polylectal Grammar. Journal of Nigerian Languages and Literature, 2, 56-61.

Awobuluyi, O. (1978). Essentials of Yoruba Grammar (pp. 76-60). Ibadan: Oxford University Press.

Awobuluyi, O. (1992). Aspects of Contemporary Standard Yoruba in Dialectological Perspective. In A. Isola (Ed.), New Finding in Yoruba Studies (pp. 12-35). J.F. Odunjo Memorial Lecture, Series No. 3.

Awobuluyi, O. (1998). Àwọn Èka-Èdè Yorùbá.Àpéró Ẹghéèdè Yorùbá (pp. 10-15). Bodija, Ibadan: Pastoral Institute.

Bamgbose, A. (1967). A Short Yoruba Grammar (pp. 22-24). Ibadan: Heinemann Educational Book (Nigeria) LTD.

Bamgbose, A. (1990). Fonólójì àti Gírámà Yorùbá (pp. 157-160). Ibadan: University Press PLC.

Edward, J. V. (2011). Dialectology. Linguistics, 201, 1-5.

Olumuyiwa, T. (2009). The High Tone Syllable in Central Yoruba Dialects. Nordic Journal of African Studies, 18, $129-137$.

Osten, D. (1979). Typology of Sentence Negation. Linguistics, 17, 79-106.

Owolabi, K. (1989). İjìnle İtúpaḷe Èdè Yorùbá(1) Fònétî̉kì àti Foṇolojojì. Ibadan: Onibonoje Press \& Book Industries (Nig) Ltd.

Trudgill, P., \& Chambers, J. K. (1980). Dialectology. Cambridge: Cambridge University Press.

Yusuf, O. (1995). Yorùbá Àkọotun: Ní Ìlànà Onídàrọ. İjèbú-òde: Șebíotimọ Publications. 
Scientific Research Publishing (SCIRP) is one of the largest Open Access journal publishers. It is currently publishing more than 200 open access, online, peer-reviewed journals covering a wide range of academic disciplines. SCIRP serves the worldwide academic communities and contributes to the progress and application of science with its publication.

Other selected journals from SCIRP are listed as below. Submit your manuscript to us via either submit@scirp.org or Online Submission Portal.
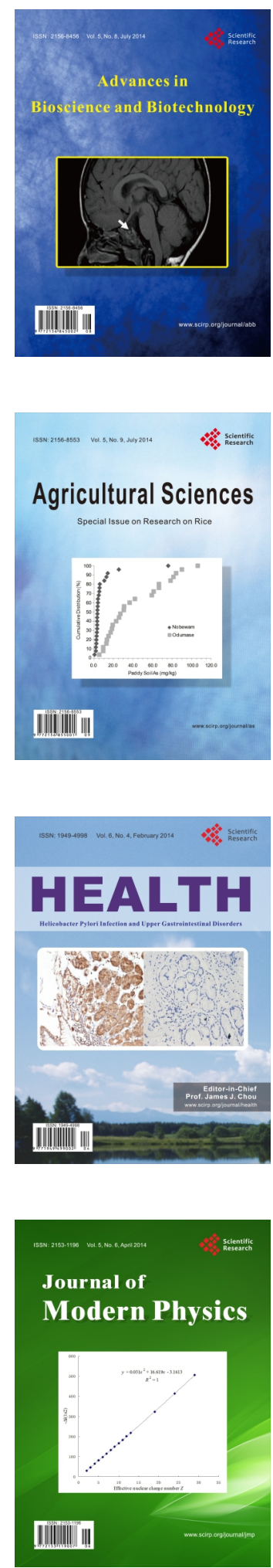
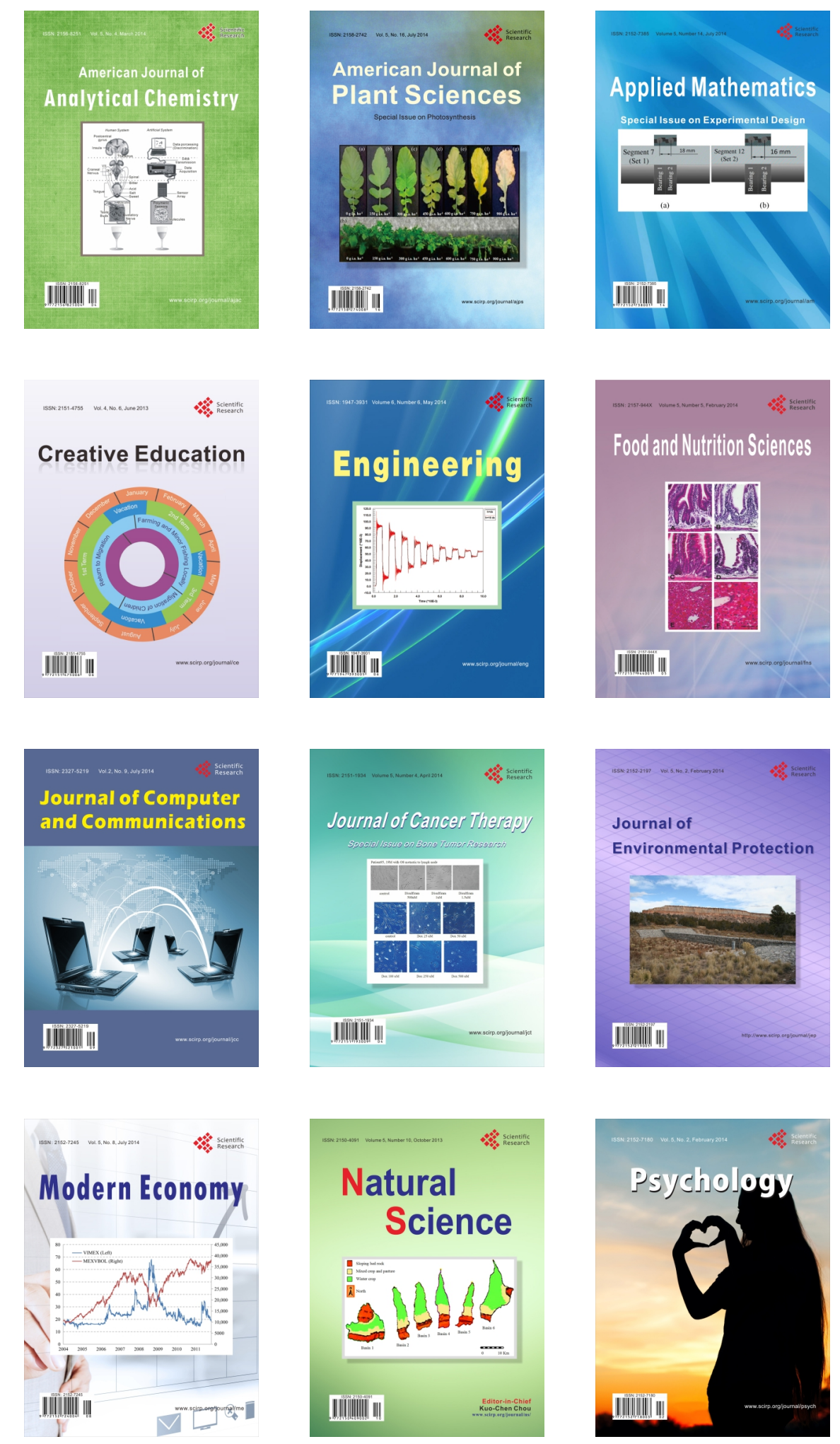